Stankiewicz W., Kolejny sukces teorii gier: nobliści z ekonomii 2012, „Ekonomia i Prawo”, Polszakiewicz B., Boehlke J. (red.), Tom XII, nr 1/2013, ss. 163-184 DOI: http://dx.doi.org/10.12775/ EiP.2013.014

\title{
KOLEJNY SUKCES TEORII GIER: NOBLIŚCI Z EKONOMII 2012
}

\section{STRESZCZENIE}

Teoria gier zdobyła uznanie w ekonomii wraz z rozwojem ekonomii matematycznej. Miało to swoje odbicie w Nagrodach Nobla, zwłaszcza w latach: 1994, 2005 i 2007. Obecne wyróżnienie Lloyda Shapleya i Alvina Rotha jest uhonorowaniem dorobku starszego wiekiem mistrza w paradygmacie teorii gier oraz młodszego uczonego, który jest także skutecznym organizatorem kojarzenia par w alokacji na rynkach dających się ująć w ramy teorii gier. Sukcesy w praktyce kojarzenia małżeństw, rekrutacji do szkół i regulacji wymiany ludzkich organów dla potrzeb transplantacji, stały się już inspiracją do dalszych badań i doskonalenia kolejnych rynków.

Słowa kluczowe: teoria gier, teoria stabilnych alokacji, praktyka projektowania rynków Klasyfikacja JEL: A, B, C7

\section{ANOTHER SUCCESS FOR GAME THEORY: NOBEL LAUREATES IN ECONOMIC SCIENCES IN 2012}

\section{SUMMARY}

Game theory has earned recognition in economics along with the development of mathematical economics. It was reflected in Nobel Prizes, especially in 1994, 2005

* Wacław Stankiewicz, Prywatna Wyższa Szkoła Businessu, Administracji i Technik Komputerowych w Warszawie. ul. Bobrowiecka 9, 00-728 Warszawa, waclawstankiewicz@poczta. onet.pl. 
and 2007. Lloyd Shapley and Alvin Roth award honours the achievements of a distinguished, elderly champion in the paradigm of game theory and a younger scholar who is also an effective organiser of matching pairs in the allocation of markets which fit the framework of game theory. Successes in marriage matchmaking, school recruitment and regulations of the exchange of human organs for the purpose of transplantation have already become an inspiration for further research and new markets improvement.

Keywords: game theory, theory of stable allocations, practice of market design JEL Classification: A, B, C7

\section{WSTĘP}

Wyraźna porażka specjalistów prognozujących coroczny werdykt jury $\mathrm{Na}-$ grody Nobla w dziedzinie ekonomii, którzy nie wymienili dwóch zwycięzców - znanych wszak w środowisku dynamicznie rozwijanej teorii gier, ale widocznie niezabiegających o szerszą popularyzację. Zarówno Lloyd Stowell Shapley (ur. 1923), jak i Alvin Elliot Roth (ur. 1951) są dobrze znani jako przedstawiciele elity amerykańskiej myśli ekonomicznej. Nie było jednak zaskoczenia $\mathrm{z}$ określeniem teorii gier, jako obszaru ekonomii generującego wciąż nowe koncepcje. Aby przybliżyć jeszcze dokładniej miejsce w paradygmacie tej teorii, zamierzam tu przedstawić, $\mathrm{w}$ miarę poprawnie, argumentację Jury Nagrody Nobla, ujętą tak oto - prosto, ale inspirująco - „Za teorię stabilnych alokacji i praktykę projektowania rynków”.

Pytanie za co konkretnie została zdobyta tak ceniona w świecie nagroda, w tak trudnej nauce i przy ostrej konkurencji ośrodków myśli ekonomicznej. Czy trafnie efekt wysiłku dwóch uczonych zdefiniowano i wyodrębniono, pamiętając o wskazówce filozofii i metodologii, że trzeba uwzględniać dialektykę więzi teorii z praktyką. To jest zaiste inspirujące, kiedy wysoką nagrodę (także pieniężną) uzyskują razem dwaj uczeni - znacznie różniący się wiekiem - i dwa czynniki rozwoju społeczno-gospodarczego - dojrzała już do popperowskiej falsyfikacji teoria stabilnej alokacji i potwierdzona działaniami w dużej skali praktyka projektowania rynków.

Przed prezentacją dorobku obu laureatów bardzo krótko przypominam o miejscu obecnego wyróżnienia we współczesnej myśli ekonomicznej i o tych uczonych, którzy zasłużyli już na taką nagrodę za osiągnięcia w teorii gier, zapewniając jej tak znacząca rolę w kreacji rzeczywistości społeczno-gospodarczej. 


\section{OD ZABAWY DO WYŻYN MATEMATYKI}

Koncepcja homo ludens to tylko kolejna próba zrozumienia człowieka myślącego w sytuacji zabawy towarzyskiej, którą zwyczaj zamknął w pewne zasady a instynkt posiadania uzbroił w motyw zysku i hazardu. W sposób oczywisty także homo economicus znajduje własne poletko w grze, jego instytucje wymiany, własności, kontraktowania i podejmowania ryzyka stały się od dawna inspiracją do sięgania po sprawne narzędzia. Coraz silniej koncepcja ilościowego traktowania problemu gry wiodła pokolenia ludzi do sezamu nauki i arsenału matematyki ${ }^{1}$. Ślady stosowania zasad przypominających teorię gier w traktatach społeczno-ekonomicznych znajdujemy już w myśli antycznej i średniowiecznej, ale dopiero dzieło Cournota z 1838 r., poświęcone teorii bogactwa, oparte na wykorzystaniu analizy matematycznej, stało się wyraźną datą wejścia teorii gier do ekonomii.

Szerokie horyzonty dla wykorzystania rozwoju teorii gier otwarła doktryna marginalizmu, głoszona przez subiektywną szkołę austriacką i wspierana przez matematyczną szkołę lozańską. Koncepcja użyteczności krańcowej stała się magnesem przyciągającym zwolenników kwantyfikacji. Raczkująca teoria dwuosobowej gry zerowej oraz wyzwanie ze strony specjalistów teorii gier kooperacyjnych i aksjomatyzacji ujęć problemowych przyniosły doniosły sukces naukowy. W 1944 r. Oskar Morgenstern (1902-1977) i John von Neumann (1903-1957) opublikowali dzieło, uznane już za klasyczne, pod tytułem Teoria gier i postępowanie ekonomiczne (Theory of Games and Economic Behavior).

Obaj autorzy pochodzili z liberalnych Austro-Węgier, studiowali i wykładali także na znanych uczelniach niemieckich, szwajcarskich i amerykańskich. Nic dziwnego, że i obecnie zwolennicy szkoły austriackiej włączają ich do grona swoich mistrzów. Udane scalenie koncepcji matematycznych Neumanna i inspirujących badań Morgensterna nad rynkami kapitałowymi i poszukiwaniem racjonalnych wyborów w relacjach podmiotów gospodarczych, stało się ważnym przełomem w szybkim rozwoju ekonomii matematycznej. Osiągnięcia $\mathrm{w}$ tej dziedzinie zostały uhonorowane prawie natychmiast po decyzji Sveriges Riksbanku w 1968 r. o ufundowaniu Nagrody Nobla w Ekonomii.

1 Zwracam uwage na tekst: M. U. Killion, Relation of Game Theory to Economic History and Marginalism, http://mpra.ub.uni-muenchen.de/13380/1/MPRA_paper_13380.pdf [data pobrania: 4.01.2013]. Warto sięgnąć do jasnego wykładu: A. Blajer-Gołębiewska, M. Zielenkiewicz, Teoria gier jako narzędzie ekonomii XX i XXI wieku, [w:] D. Kopycińska (red.), Teoretyczne aspekty gospodarowania, Wyd. Katedry Mikroekonomii Uniwersytetu Szczecińskiego, Szczecin 2005, s. 77-86. 
Warto w tym miejscu przypomnieć, że w 1970 r. to wyróżnienie otrzymał Paul Samuelson (1915-2009), którego Zasady analizy ekonomicznej (1947) i wciąż wznawiana od 1948 r. Ekonomia, przyczyniły się do triumfu matematyki jako języka potrzebnego ekonomii w całym jej rozwoju. Jury ujęła krótko wkład laureata, jako trud naukowca, który nie tylko rozwinął statyczną i dynamiczną teorię zjawisk społeczno-gospodarczych, ale aktywnie działał na rzecz podniesienia poziomu analizy nauki ekonomicznej. Otwarta została przestrzeń dla koncepcji syntezy neoklasycznej, w której kierunki i nurty wielu doktryn prowadzą twórcze dyskusje. Ramy ekonomii matematycznej objęły już szereg dyscyplin naukowych, w tym - ekonometrię, legitymującą się licznymi sukcesami w badaniach empirycznych. Wśród Noblistów w dziedzinie ekonomii znalazło się już wielu uczonych czerpiących natchnienie z dorobku Samuelsona, a wśród nich także grupa specjalistów z teorii gier.

Do historii myśli ekonomicznej przeszła już Nagroda Nobla przyznana w roku 1994 jednocześnie trzem uczonym „za ich pionierską analizę równowagi w teorii gier niekooperatywnych”. W gronie laureatów znaleźli się: dość już znany w nauce John Forbes Nash (ur. 1928) z Princeton, drugi Amerykanin, Węgier z pochodzenia John Charles Harsanyi (1920-2000) z Berkeley i Niemiec Reinhard Selten (ur. 1930) z uniwersytetu w Bonn. Zaskoczeniem dla wielu środowisk było „przeniesienie do cywila” wojskowych badań operacyjnych, wielce zasłużonej dla Pentagonu, NATO i UW dyscypliny naukowej. Teoria gier miała jednak już swoją historię w praktyce militarnej, w ćwiczeniach i sztuce wojennej, a współcześnie w międzynarodowych stosunkach kształtujących bezpieczeństwo regionalne i globalne tak wrażliwe na sytuacje niepełnej informacji partnerów. Każdy z laureatów szedł odmienną ścieżką drogą do kariery naukowej.

W dramatycznych okolicznościach powstawała koncepcja równowagi Nasha, ponieważ jej autor walczył z własną groźną biologiczną chorobą i musiał zmierzyć się z pojęciem równowagi występującą $\mathrm{w}$ sytuacjach ekonomicznych, ale wciąż traktowaną nieprecyzyjnie. Nash zamknął początkowo obszar badań do znanych już form gry rywalizacyjnej i sytuacji duopolu, następnie wyróżnił dwie strategie pozwalające uzyskać równowagę niezespołowo, tj. w warunkach dążenia do maksymalizacji tylko własnego dobrostanu. Twierdzenie Nasha weszło do teorii gier jako podstawowa zasada: trzeba zawsze wybierać strategię zakładając, że twoi konkurenci będą działać we własnym interesie.

Najstarszy z trójki - Harsanyi - urodził się Budapeszcie w rodzinie aptekarza, który przeszedł z judaizmu na katolicyzm, miał ogromne uzdolnienia matematyczne, ale wola ojca i wybuch wojny zmusiły do studiowania farmakologii, służby w oddziałach przymusowej pracy i szukania schronie- 
nia w klasztorze dominikanów. Próba studiowania socjologii na uniwersytecie w Budapeszcie i założenia rodziny skończyły się ucieczką do Austrii i emigracją do Australii. Znalazł tam warunki do studiowania ekonomii i awansowania w pracy naukowej. Kiedy jego zainteresowanie teorią gier nie mogło być zaspokojone w Australii, przeniósł się w 1959 r. do USA i związał się z University of California aż do śmierci. Pracował w zespołach naukowo-badawczych, także świadczących usługi w procesach kontroli zbrojeń strategicznych. W środowiskach naukowych podkreśla się jego wkład do teorii gier $\mathrm{z}$ niepełną informacją, a wskazuje się również na te zagadnienia etyki i socjologii, które mają istotne powiązania $\mathrm{z}$ teorią gier.

Wojna nie oszczędziła także Seltena, który urodził się we Wrocławiu, wtedy niemieckim, w rodzinie żydowsko-protestanckiej, która musiała szukać schronienia w Saksonii, Austrii i Hesji, przy czym młody Reinhard pracował fizycznie na farmie aż do 1947 r. W latach 1951-1957 studiował matematykę i ekonomię na Uniwersytecie Goethego we Frankfurcie nad Menem i poznał teorię gier, którą wkrótce wykorzystywał i rozwijał w programach naukowobadawczych. Nawiązał bezpośrednie kontakty z O. Morgensternem, Harsanyi i Aumannem. Odnotowano jego publikacje z zakresu teorii gier związanej z funkcjonowaniem przedsiębiorstw. Zajmował już wysokie stanowiska w poważnych uczelniach, a od 1972 r. kierował Instytutem Ekonomii Matematycznej w Bielefeld, rozwijając skutecznie nową dziedzinę - ekonomikę eksperymentalną. Pojawiły się nowe koncepcje teorii równowagi w różnego typu grach. Analizując koncepcję teorii gier zajął się problemem selekcji (wyboru) jednego z pośród wielu punktów „równowagi Nasha” i zaproponował ostre reguły kolejnych eliminacji, wprowadzając pojęcie „doskonałości subgry” (subgame perfectness). Wspomnę, że Selen, już jako Noblista, utrzymuje kontakty z Uniwersytetem Ekonomicznym we Wrocławiu (tytuł dhe w 2004 r.) i uczestniczył $\mathrm{w}$ kilku polskich imprezach naukowych.

Nagroda Nobla w roku 2005 dla Aumanna i Schellinga spotkała się z akceptacją większości światowych ośrodków naukowych, przygotowanych już do traktowania teorii gier, jako jądra paradygmatu głównego nurtu myśli ekonomicznej. Dwaj laureaci od lat należeli do ścisłej czołówki specjalistów amerykańskich i wykładowców zapraszanych na wykłady w państwach akceptujących politykę rozbrojenia i zrywających z systemem socjalistycznym. Niezwykle bogaty dorobek obu uczonych werdykt jurorów ujął prosto jako „zawierający rozszerzenie naszego rozumienia konfliktu i współdziałania poprzez analizę stosowaną w teorii gier”. Mogę tylko wymienić część ich osiągnięć.

Zaczynam od Thomasa C. Schellinga (ur. 1921), z University of Maryland, wybitnego politologa i autora traktatów The Strategy of Confict (1960) i Arms and Influence (1966), W sytuacji grożącej konfliktem z użyciem bra- 
ni masowej zagłady, koncepcja analizy prezentowanej przez Schellinga opierała się na pojęciu „zachowań konfliktowych” (conflict bebavior), kiedy to strony (gracze!) losowo (randomizacja) stosują groźby i przyzwolenia, a korzystnym staje się wybór od strategii odstraszania. Nic dziwnego, że ten sposób analizy była akceptowany w amerykańskiej polityce i dyplomacji. Warto także przypomnieć, że Schelling czynił wiele dla walki z przejawami różnych rodzajów dyskryminacji grup społecznych ${ }^{2}$.

Spośród publikacji Roberta J. Aumanna (ur. 1930) wymieniam na pierwszym miejscu jego obszerne hasło Game theory w encyklopedii New Palgrave, które wciąż zdumiewa jasnością wykładu dziejów i precyzją wyjaśniania koncepcji podawanych w języku matematycznym ${ }^{3}$. W załączonej bibliografii znajdujemy prawie wszystkie liczące się pozycje wymienionych tu noblistów i wyraźne sugestie na temat perspektyw rozwoju ekonomii matematycznej i teorii gier. Imponujący dorobek Aumanna daje się podporządkować teorii podejmowania decyzji interakcyjnych, przy czym ze wskazaniem na rolę utrzymywania się długookresowych i powtarzających się relacji stron konfliktu. Badania empiryczne dowodzą, że gry krótkoterminowe mają zwykle zbyt restryktywny charakter. Teoria gier powtarzalnych - ograniczonych w pewnym przedziale czasu i nieograniczonych - jest teraz ujmowana przez Aumanna jako punkt wyjścia do badań empirycznych. Rzeczywistość jest przepełniona współdziałaniem wielu różnorodnych i nieregularnych uczestników, a zrywanie kontraktów nie daje się przewidzieć. Tezy Aumanna i jego zwolenników znalazły przychylny odbiór wśród badaczy takich konfliktów, jak wojny cenowe i gospodarcze, negocjacje płacowe i funkcjonowanie szarej strefy. Twierdzi się, że Aumann nie tylko wzbogacił teorię gier, ale także wniósł wiele cennych koncepcji do współczesnej metodologii nauk.

Ten krótki przegląd osiągnięć nurtu matematycznego we współczesnej myśli ekonomicznej kończę przypomnieniem Nagrody Nobla w 2007 r. Wtedy uhonorowano zespół (nieformalny!) złożony z mistrza Leonida Hurwicza (1917-2008) i wybitnych specjalistów z Harvardu - Erica Maskina (ur. 1950) i Rogera Myersona (ur. 1951), korzystających ze zdobyczy teorii gier także w badaniach empirycznych i koncentrujący się właśnie na problematyce projektowania mechanizmów gospodarczych ${ }^{4}$. Laureaci opracowali atrakcyjną konstrukcję nośną dla potrzeb projektowania mechanizmów społecznych

2 T. C. Schelling, Micromotives and Macrobehavior, Norton 1978.

${ }^{3}$ R. J. Aumann, Game theory, "The New Palgrave. A Dictionary of Economics”, 1998, vol. 2, s. $460-482$.

${ }^{4}$ W. Stankiewicz, O projektowaniu mechanizmów społecznych, „Ekonomista”, 2009, nr 3, s. $399-411$. 
i ekonomicznych, posługując się podejściem instytucjonalnym i algorytmami teorii gier. Działali w atmosferze współpracy z tym samym środowiskiem naukowym, w którym wyróżnili się teraz Shapley i Roth.

\section{SHAPLEY - MISTRZ W CZOŁÓWCE TWÓRCÓW PARADYGMATU TEORII GIER}

Lloyd Stowell Shapley jest przedstawicielem pokolenia statystycznie i dość powszechnie zaliczanego do w pełni dojrzałego, ale niepozbawionego jeszcze weny twórczej. Urodził się 2 czerwca 1923 r. w Cambridge (stan Massachusetts) w rodzinie wybitnego astronoma Harlowa Shapleya i w środowisku zapewniającym wszelkie warunki do kariery naukowej. Studia na Uniwersytecie Harvarda (matematyka i ekonomia) rozpoczął w 1943 r., ale musiał je zaraz przerwać i jako sierżant w amerykańskim korpusie lotnictwa sił lądowych uczestniczył w wojnie $\mathrm{z}$ Japonią na froncie chińskim, a za złamanie szyfrów przeciwnika był odznaczony. Pierwsze kroki dorosłego życia przyniosły wyzwania, które stały się inspiracją łączenia studiów wysoce teoretycznych z wyzwaniami dynamicznej i zróżnicowanej praktyki.

Po demobilizacji powrócił do Harvardu, w 1948 r. miał już dyplom bakałarza matematyki, a zainteresowania militarne ułatwiły mu pracę $\mathrm{w}$ słynnym RAND Corporation i dalsze studia w Princeton University, gdzie uzyskał doktorat. Teza pracy doktorskiej i jej późniejsze modyfikacje stanowią obecnie znaczące fragmenty teorii gier. Autor podjął obowiązki profesora w University of California, Los Angeles, pozyskał wielu zdolnych uczniów i stał się uznanym mistrzem $\mathrm{w}$ gronie mistrzów teorii gier. $Z$ bogatej bibliografii publikacji Shapleya i z wybranych źródeł jego analityków - zwolenników, krytyków i przede wszystkim młodych uczonych podejmujących trud rozwinięcia teorii gier - odczytujemy teraz dwie współzależne koncepcje, stanowiące istotny wkład noblisty do współczesnej teorii gier: pierwsza, ma już szeroko znaną nazwę „Wartości Shapley'a” (Shapley value); druga, nie ma takiej zwartej nazwy, bowiem jest już traktowana jako „rdzeń ogólnego rozwiązania w teoriach koalicyjnych" (core as general solution concept for cooperatives games), Mamy tu podane warunki istnienia rdzenia (jądra, istoty, sedna) gry koalicyjnej i powiązanie $z$ algorytmem „odroczonej zgody”, związanym ze stabilną alokacją zysków w koalicji. Tylko w sposób ogólny, odsyłając czytelnika do głębszych ujęć, kreślę kilka tez dotyczących obu koncepcji Shapleya ${ }^{5}$.

\footnotetext{
${ }^{5}$ Przy studiowaniu tych zagadnień pożyteczne jest zaglądanie do świetnego wykładu Tadeusza Płatkowskiego pt. Wstęp do teorii gier, Uniwersytet Warszawski, Warszawa 2012.
} 
Oryginalna koncepcja pojęcia wartość, przydatna w teorii gier koalicyjnych, znalazła się w skromnym przyczynku zatytułowanym $A$ Value for $n$-person Games , opublikowanym w 1953 r. w Annałach Princeton University ${ }^{6}$. Dopiero w 1988 r. koncepcja zdobywa szeroki rozgłos jako „Wartość Shapley'a”, kiedy to pod redakcją Alvina Rotha ukazała się księga esejów ku czci mistrza ${ }^{7}$. Od tego czasu nazwa taka jest już w popularna w literaturze naukowej. Korzystam z podręcznika T. Patkowskiego, ale aby raczej w języku potocznym przybliżyć i przypomnieć zalety tego fragmentu teorii gier8.

Gry kooperacyjne (GK) są to $n$-osobowe gry, w których gracze mogą tworzyć koalicje jako podzbiory gry. Każdej koalicji można przypisać wartość i żądać by każdy gracz miał wypłatę nie mniejszą niż gdyby nie był w koalicji. Właśnie taki podział wartości koalicji (sumy wypłat) między jej członkami stanowi kryterium dla decyzji rozwiązania gry. Jako synonimy oceny rezultatów gry przyjmowane są pojęcia równowagi i stabilności, chociaż występuje często brak powszechnej zgody dla jednej koncepcji. Poszukiwanie takiej zgody przyniosło ciekawe propozycje. Oto jedna z nich.

Do struktury GK wprowadza się wektor wypłat $x$, jako dodatkową strukturę, która ułatwia zdefiniowanie rozwiązania i stabilności. Jeżeli taki wektor wypłat jest indywidualnie i grupowo racjonalny to określany jest jako podzial (imputacja) lub racjonalna alokacja zysków z koalicji. Stabilność podziału oznacza, że jest on koalicyjnie racjonalny. Takie postępowanie prowadzi do definicji pojęcia rdzeń koalicji, jako zbioru $\mathrm{C}(\mathrm{v}) \equiv \mathrm{C}$ stabilnych podziałów. $\mathrm{W}$ dyskusji specjalistów problem rdzenia $\mathrm{w}$ grach koalicyjnych (core solution in game theory) jest źródłem inspiracji do coraz lepszych rozwiązań i podnoszenia poziomu naukowości nie tylko teorii gier. Nic też dziwnego, że wokół pojęcia „Wartość Shapley’a” narosło mnóstwo nowych ujęć, wśród których trzeba poruszać się ostrożnie.

Oto pozornie najprostsze ujęcie: „Wartość Shapley’a” występuje w języku teorii gier koalicyjnych GK jako wektor $n$ liczb rzeczywistych, spełniających 4 aksjomaty: 1) racjonalności grupowej, 2) symetrii, 3) występowania graczy nieistotnych, 4) addytywności. Pamiętając o tym, że aksjomat jest twierdzeniem przyjętym bez dowodu, pewnikiem i prawdą oczywistą, dość często nie uchylamy się od wątpliwości przy określeniu „wartości Shapley'a” jako koniecznej do uznania podziału zysku (wypłat) z gry koalicyjnej za „sprawiedli-

${ }^{6}$ L. S. Shapley, A Value for n-person Games, „Annals of Mathematical Studies”, 1953, vol. 28, s. $307-317$.

7 A. E. Roth (ed.), The Shapley value, essays in honor of Lloyd S. Shapley, Cambridge University Press 1988.

${ }^{8}$ T. Płatkowski, op. cit., rozdz. 11 i 12. 
wy". Jako uczony wielkiej klasy Shapley prowadził badania zespołowe i publikował oryginalne koncepcje we współautorstwie ze specjalistami ekonomii matematycznej i teorii gier. Oto kilka przykładów.

W 1954 r. ukazała się płodna koncepcja indeksu sity Shapleya-Shubika, jako narzędzia pomiaru siły uczestników gry, w której wykorzystuje się metodę głosowania - voting game ${ }^{9}$. Martin Shubik (ur. 1926) należy do czołówki amerykańskiej myśli ekonomicznej, tworzy nie tylko dla teorii gier i ekonomii matematycznej, ale także instytucjonalnej, eksperymentalnej i na użytek praktyki systemu finansowego. Autorzy potraktowali legislatury, rady nadzorcze i inne ciała podejmujące decyzje przez głosowanie jako koalicje graczy mających swoje preferencje. Wykryli, że siła koalicji nie jest wprost proporcjonalna do jej rozmiarów. Zaproponowali jej mierzenie poprzez frakcje możliwych sekwencji głosowania, które prowadzi koalicję do głosowania gwarantującego zwycięstwo. Istnieje już bogata informacja weryfikująca przydatność indeksu w wielu dziedzinach praktyki.

Wieloletnia współpraca z Robertem Aumannem przyniosła obu uczonym szerokie uznanie i liczne grono zdolnych uczniów. Tutaj wspomnę tylko o ich książce pod tytułem, którego polskie tłumaczenie może być narażone na zarzut nietrafności ${ }^{10}$. Udałem się przeto do tekstu polskiego wybitnego specjalisty teorii gier prof. Marcina Malawskiego z Akademii Leona Koźmińskiego, który w periodyku tej uczelni przybliżył nam sylwetkę Aumanna jako Noblisty i jednocześnie wyjaśnił przystępnie pojęcie „non-atomic game” na polskie "gry bezatomowe"11. Sugestywne jest przybliżenie czytelnikowi zbioru graczy jako odcinka $[0,1]$, w którym każdy $\mathrm{z}$ nich jest reprezentowany przez inny punkt tego odcinka. Pojawia się obiekt analizy jako zbiór rynków z nieskończonymi zbiorami nieskończenie małych graczy! Decyzja pojedynczego gracza nie ma wpływu na wynik gry i tylko odpowiednio duża ich grupa może to spowodować. Pamiętajmy - gry bezatomowe to są gry prowadzone nie przez zbiór jednostek, lecz przez wymierną przestrzeń, której wymiernymi są zbiory zwane koalicjami.

${ }^{9}$ L. S. Shapley, M. Shubik, A Method for Evaluating the Distribution of Power in a Committee System, „American Political Science Review”, 1954, vol. 48, s. 787-792. Por. tych autorów On Market Games, "Journal of Economic Theory”, 1967, vol. 1, s. 9-25 oraz The Assignment Game I: The Core, „International Journal of Game Theory”, 1971, vol. 1, s. 111-130.

10 R. J. Aumann, L. S. Shapley, Values of Non-Atomic Games, Princeton University Press 1974. Por. także L. S. Shapley, Values of large market games: Status of the problem, RM-3957-PR, The Rand Corporation, Santa Monica 1964.

${ }_{11}$ M. Malawski, Robert Aumann, „Zeszyty Naukowe Akademii Leona Koźmińskiego”, 11 czerwca 2009 r. 
Współautorzy książki rozwinęli szeroki front badań i należy sądzić, ze pojawia się nowe wyzwania $\mathrm{w}$ ramach paradygmatu teorii gier i nawet nurtów nauki ekonomicznej.

Przytoczę jeszcze dość rzadki w kręgach uczonych przypadek uznania pierwszeństwa w sformułowania ważnej tezy naukowej innemu autorowi. Taki przypadek zaistniał w 1967 r. po opublikowaniu przez Shapleya artykułu o warunkach, które pozwalają uznać, że rdzeń gry koalicyjnej jest pusty. Odkryto, że wcześniej zagadnienie to rozwiązała aspirantka Leningradzkiego Uniwersytetu Olga Nikołajewna Bondariewa (1937-1991). Pech chciał, że jej publikacja ukazała się wprawdzie w poważnych „Problemach Kibiernietiki”, ale po rosyjsku i została przeoczona na Zachodzie ${ }^{12}$. Trzeba podkreślić zachowanie Shapleya - uznał ten fakt, pogratulował pierwszeństwa młodej Rosjance i pomógł wdrożyć pojęcie teorematu Bondariewa-Shapleya w światowych dyskusjach o teorii gier. Teoremat głosi, że rdzeń gry nie jest pusty wtedy i tylko wtedy, kiedy gra jest zrównoważona (balanced).

Studiując współczesną myśl ekonomiczną, zwłaszcza okres po II wojnie światowej i dzieje Nagrody Nobla w ekonomii, korzystałem z pożytkiem z syntezy zawartej w publikowanych tekstach ich laureatów. Czekałem na taki wykład Lloyda Shapleya w nadziei na głębsze poznanie doktryny ekonomicznej mającej już wpływ na główny nurt nauki ekonomicznej i tak dynamiczny jej składnik jakim jest teoria gier. Na użytek dydaktyki i wymianę poglądów w naszym środowisku uczę się wciąż w miarę pożytecznych ujęć współżycia ze specjalistami ekonomii matematycznej. Tym razem poczułem się zawiedziony - mistrz Shapley dokonał wyboru rzadko spotykanego wśród noblistów, redukując wykład wręcz niebezpiecznie. Organizatorzy imprezy dali obu Laureatom szkolną godzinę na wykład, a chyba ten przyjazny duet sam podzielił czas wykładu - 7 minut dla starszego mistrza i aż 43 dla Rotha, a publikacja w pdf objęła odpowiednio $72 \mathrm{~Kb}$ i 2,38 MB. Musiałem cieszyć się oglądając na ekranie piękny przykład postawy prawdziwych uczonych, a jednocześnie $\mathrm{z}$ trudem pogodzić się $\mathrm{z}$ tak krótką prezentacją tak poważnego osiągnięcia naukowego.

Opublikowany tekst nosi dwa wytłuszczone tytuły Teoria gier i Gry alokacyjne, natomiast w adresie Internetowym mamy podtytuł Assignment Games. The Mathematics of Matching. $Z$ bogatego plonu własnej twórczości naukowej wykładowca przedstawił istotne metody przechodzenia od konceptualizacji do operacjonalizacji, a w ramach rozwijanej teorii gier skupił uwa-

12 O. N. Bondareva, Some applications of linear programming methods to the theory of cooperative games in Russian, „Problemy Kybernetiki”, 1963, vol. 10, s. 119-139; L. S. Shapley, On balanced sets and cores, „Naval Research Logistics Quarterly”, 1967, vol. 14, s. 453-460. 
gę na grach koalicyjnych, zwłaszcza zajmujących się alokacją i kojarzeniem. W trosce o słuchaczy i czytelników posłużył się dość już upowszechnionym algorytmem kojarzenia stabilnego małżeństwa ${ }^{13}$. Posługując się prostym grafem wykładowca dowiódł, że algorytm w skończonej liczbie kroków daje stabilne rozwiązanie, Jest to najlepszy możliwy wynik dla grupy proponującej kojarzenie par małżeńskich. W procesie kojarzenia wykorzystuje się zasadę odroczonej zgody (deferred acceptance).

Trzeba pogodzić się z faktem, że studiowanie dorobku mistrzów w ekonomii nie jest łatwe, ale może obfitować w interesujące i pożyteczne ujęcia, służące dyskusjom.

\section{ALVIN ROTH - WIELKI UCZONY I SKUTECZNY SWAT (MATCH-MAKER)}

Przed omówieniem tych stron dorobku naukowego A. Rotha, zwrócę uwagę na próbę przypisywania uczonych ekonomistów do miejsc w hierarchicznym ujęciu naukowej myśli ekonomicznej, a także do nieco już lepiej zdefiniowanych szkół i doktryn. Pamiętając o niegasnących sporach na temat głównego nurtu (mainstream) i o kompromisie w dzieleniu ekonomistów na orto- i heterodoksów, odwołam się do poręcznego chwytu amerykańskich specjalistów $^{14}$.

Nie odrzucając tezy o znaczeniu doktryny neoklasycznej, wciąż z powodzeniem głoszonej $\mathrm{w}$ prominentnych uczelniach, a w odniesieniu do ekonomii amerykańskiej akceptujących jej integrację z neokeynesizmem, posłużyli się oni ogólnymi charakterystykami znanych uniwersytetów i - dowcipnie! - podzielili środowisko uczonych na dwie wielkie ortodoksalne szkoły myśli ekonomicznej, nazywając je szkołami „słonej” i „słodkiej wody” (saltwater and freshwater"). Jako położone bliżej wschodnich i zachodnich wybrzeży USA do grupy szkoły słonej wody pasują: Berkeley, Harvard, Cornell, MIT, Pennsylvania, Princeton, Columbia, Duke, Stanford i Yale. Natomiast sąsiedztwo Wielkich Jezior pozwala do grupy słodkiej wody włączyć: Chicago, Karnegie Mellon, Rochester i Minnesota. Pierwsza szkoła akceptuje keynesowskie ujęcie interwencji państwa, druga zachowuje w tej sprawie duży sceptycyzm.

${ }^{13}$ L. S. Shapley, D. Gale, College Admissions and the Stability of Marriage, „The American Mathematical Monthly”, 1962, vol. 69, s. 9-15.

14 P. Kilborn, 'Fresh water' Economists Gain, „New York Times”, http://query. Nytimes.com [data pobrania: 4.01.2013]. 
Do której szkoły możemy przypisać naszych Laureatów? Nie mamy kłopotu z mistrzem - Lloyd Shapley najsilniej był i jest związany z Kalifornią i Massachusetts, co nie oznacza, że nie brał udziału w pracach naukowych wielu innych ośrodków. Młodszy wiekiem Alvin Roth należy prawie jednoznacznie do tej samej szkoły, dzięki karierze w Columbia i Stanford. Dla wsparcia tezy o znaczeniu tradycji i wpływie ducha opiekującego się pewnym miejscem (taki genius loci) przytoczę jeszcze jeden fakt. Obaj nobliści byli związani z RAND Corporation i realizacją zamówień Pentagonu w ramach szybko rozwijających się badań operacyjnych. Za bezsporny trzeba ten fakt uwzględnić w analizie koncepcji teorii gier i projektowania rynków prowadzących na szczyty współczesnej myśli ekonomicznej.

Dialektyka powiązań militarnych i gospodarczych daje znać o sobie już w pradziejach ludzkości, jako współzależność instynktów łupieżczości, posiadania, wymiany i ciekawości. We współczesnej matrycy instytucjonalnej obszar przenikania się tych szczególnych płyt „tektonicznych” rodzi konflikty, eskalujące aż do wojen totalnych $z$ użyciem środków masowej zagłady. Można także dowieść, że postęp techniczny i atrakcyjność imperializmu uczyniły procesy konwersji produkcji pokojowej na militarną relatywnie prostą. Nic dziwnego, że takie poczynania, jak wyścig zbrojeń, wzajemne korzystanie ze zdobyczy rewolucji naukowo-technicznych, pojawienie się kompleksu wojskowo-przemysłowego są problemami aktualnymi i takimi pozostaną. Narodziny dyscypliny naukowej pod nazwą „badania operacyjne” (operations research) wiążą się z totalnym charakterem II wojny światowej i mają swoje zalążki w szeroko już rozwiniętej ekonomice obrony, jako nauce o znaczeniu potencjału gospodarczego w konfliktach zbrojnych.

Od 1940 r. Wielka Brytania była zagrożona klęską na Atlantyku, ponieważ jej logistyka wymagała zabezpieczenia konwojów z dostawami amerykańskimi, atakowanych skutecznie przez niemieckie okręty podwodne. Sięgnięto do matematyki i opracowano wytyczne dla producentów uzbrojenia, a sztabowców uczono zrozumienia istoty algorytmów i metod raczkującej informatyki. W Stanach Zjednoczonych skala i tempo rozwoju badań operacyjnych należały do bezprecedensowych. Historia RAND Corporation jest ważnym fragmentem analizy osiągnięć współczesnej amerykańskiej myśli ekonomicznej i jest tu potrzebna dla poznania przynajmniej części dorobku Shapleya i Rotha ${ }^{15}$.

Potencjał naukowy USA w II wojnie światowej zasłużył się dla zwycięstwa we wszystkich praktycznie dziedzinach, a zwłaszcza w produkcji syste-

15 Zasłużony popularyzator RAND Corp - A. Abella, The RandCorporation: The Think TanknThat Controls America, http://mentalfloss.com/article/22120/rand-corporation [data pobrania: 4.01.2013]. 
mów uzbrojenia. Projekt Manhattan dostarczył pierwszą broń atomową, a cały system gospodarki wojennej stał się przykładem realizacji strategicznych programów społeczno-gospodarczych. Start do rangi światowego imperium przyniósł m.in. powołanie przez dowódcę Sił Powietrznych gen. Henry Arnolda zespołu wybitnych naukowców, pracujących na rzecz zdobycia przez USA czołowego miejsca $\mathrm{w}$ technologii militarnej. Broń rakietowa stała się groźnym wyzwaniem po ujawnieniu możliwości bomby atomowej. Współpraca z koncernem samolotowym Donalda Douglasa przyniosła w 1948 r. organizację w Santa Monica organizacji non-profit RAND Corporation. Szacuje się, że obecnie zatrudnia ona ok. 1,6 tys. pracowników w 3 amerykańskich i 3 europejskich ośrodkach. Z całą mocą podkreśla się, że RAND zajmuje się problemami globalnymi, badaniami kosmosu i działa na rzecz światowego pokoju. Nie musimy jednak wierzyć, że potrzeby bezpieczeństwa USA zeszły na daleki plan. Badania operacyjne dawno przekroczyły granice nauk wojskowych i uprawiane są z powodzeniem w sektorze cywilnym.. Traktowane są jako generatory doskonalszych metod $\mathrm{w}$ procesie podejmowanych decyzji, a - szerzej - jako gałąź matematyki. Nic przeto dziwnego, że wśród osób mających znaczenie dla rozważanych tu zagadnień znajdujemy także kilku związanych z RAND Corporation. Oto kilka faktów.

Współczesna myśl ekonomiczna zawdzięcza wiele koncepcjom Kennetha Arrowa (ur. 1921), współtwórcy teorii wyboru społecznego. Wymieniłem już Paula Samuelsona, Johna Nasha, Johanna von Neumanna i Thomasa Schellinga. Dodaję jeszcze Harry Markowitza (ur. 1927), który pracował w RAND w latach 1952-1963, rozwijał teorię racjonalnych zachowań w warunkach niepewności i zasady programowania w informatyce, a Nobla zdobył w 1990 r. Warto także wspomnieć, że obecny lider nowej ekonomiki instytucjonalnej Oliver E. Williamson (ur. 1932), zdobywał wiedzę w RAND na długo przed uzyskaniem Nagrody Nobla w 2009 r.

Powracam do analizy aktualnych noblistów. Lloyd Shapley, który z wojska wrócił na Harvard i w 1948 r. uzyskał stopień bakałarza z matematyki, potem przez rok pracował w RAND Corporation, a w Princeton University doktoryzował się w 1953 i znowu związał się z RAND w latach 1954-1981. Ten okres wykorzystał niezwykle owocnie dla rozwinięcia teorii gier i koncepcji struktury rdzenia gry. Natomiast Alvin Roth uzyskał w 1971 r. dyplom bakałarza w Columbia University właśnie z badań operacyjnych, i z tej samej dyscypliny magistra (1973) i doktora (1974) w Stanford University. Nie mam informacji o jego studiach w RAND. Roth należy do tych uczonych, dla których dostępne są najlepsze ośrodki decydujące o postępie nauki. Nie ma tu potrzeby ich wymieniania, konieczny jest natomiast wybór tych fragmentów dorobku tego Noblisty, które - jak mniemam - powinny być upowszechnio- 
ne w naszych środowiskach zainteresowanych przenoszeniem teorii do praktyki. Na początku kilka uwag o teorii i sztuce projektowania rynków, które mają tak wiele wspólnego $\mathrm{z}$ wspomnianym wyżej projektowaniem mechanizmów społecznych grupy Hurwicza ${ }^{16}$.

Przede wszystkim Roth sprecyzował zamiar scalenia jasno określonej teorii - jako zajmującej się problemem stabilnych alokacji rynkowych - z praktyką projektowania rynków - a więc tworzenia nowych lub doskonalenia istniejących. W planie swego wykładu pragnął odpowiedzieć na pytanie - jak takie stabilne alokacje i mechanizmy kojarzenia (matching) przyłączyć do pewnych rynków, które mają większy wpływ na nasze życie. Dodatkowo warto podjąć trud opracowania teorii służącej rynkom w poznawaniu preferencji uczestników wpływających na stabilizację alokacji. Teoria miała wejść do praktyki rynków pracy, szkolnictwa i systemów medycznych.

Roth uczynił wiele dla skutecznego przejścia od konceptualizacji do operacjonalizacji. Dla projektowania rynków potrzebne były ich klasyfikacje na podstawie istotnych cech. Rynki towarowe mogą być konkurencyjne i anonimowe a ich ceny o różnej mocy sprawczej, przy czym są i takie gdzie pojawienie się ceny jest czymś obrzydliwym. Rynki pracy, rekrutacje do szkół, rozmieszczenie absolwentów zrodziły rynki przypominające tradycyjne zaloty, swatanie i zawieranie małżeństw, a dla znawców teorii gier dwustronny rynek poszukiwań i zalecania się z obu stron. Wprowadzone zostaje kluczowe pojęcie „rynek kojarzenia” (matching market), a może dopasowywania, swatania (bardzo tradycyjny i ograniczony). Dowiadujemy się tam jak wiele jest rzeczy, których nie możemy po prostu wybrać.

W swoim noblowskim wykładzie Roth podkreślił wkład mistrza Shapleya i jego współautorów w budowę podstaw dla wyjścia na pole badań empirycznych i wdrożenia programów praktycznych ${ }^{17}$. Rozwiązali oni ważną kwestię stabilności rdzenia w grze na dwustronnym rynku, proponując wykorzystać algorytm odroczonej zgody (deferred acceptance algorithm). Roth i jego zespół użyli tych narzędzi dla kwantyfikacji preferencji uczestników takiego rynku. Rozwinęli także metody przydatne w projektowaniu specyficznych rynków jednostronnych, korzystając z algorytmu Davida Gale'a (top trading cycles algorithm) w analizie np. procesu poszukiwania przez kandydatów preferowa-

16 A. E. Roth, The Art of Designing Markets, „Harvard Business Review”, Oct. 2007, s. 1-8; oraz What have we learned from market design?, „Economic Journal”, 2008, s. 285-310. Warto skorzystać z dostępnych w Internecie slajdów jego wykładu z 8 grudnia 2012 r. pt. The Theory and Practice of Market Design (work in progress).

17 Por. D. Gale, L. Shapley, op. cit., oraz L. Shapley, H. Scarf, On cores and indivisibility, „Journal of Mathematical Economics", 1974, vol. 1, s. 30-44. 
nej przez siebie szkoły. Konieczne były informacje $\mathrm{z}$ case studies, uwzględniające realne zagadnienia „targowisk” (jak chyba trzeba przetłumaczyć określenie „marketplaces”), a więc uczelni, szpitali, zakładów pracy itp. ${ }^{18}$ Studiując liczne publikacje Rotha, zwłaszcza w okresie 1980-1990, i obecne jego wypowiedzi związane z otrzymaniem Nagrody Nobla wspólnie z Shapleyem, zwróciłem uwagę na skromność uczonego, szacunek dla nieformalnego wszak mistrza i próbę obiektywnego wyważenia proporcji w rozwoju współczesnej nauki ekonomicznej. Roth wskazuje na wciąż atrakcyjne pole badawcze rynków kojarzenia, prawie 30 lat wymiany poglądów w środowisku wybitnych znawców i siebie umieszcza jako ucznia i wielkiego zwolennika (big follower) koncepcji Shapleya.

Oryginalny wkład Rotha i jego najbliższych współpracowników wiąże się $\mathrm{z}$ twierdzeniem, że na dwustronnym rynku nie można zawsze zapewnić stabilne skojarzenie (zeswatanie) opierając się na zbiorze preferencji ujawnionych w sposób bezpieczny dla każdego który je ujawnia. Przypomina to postulat Hurwicza umieszczenia $\mathrm{w}$ strukturze projektowania mechanizmów społecznych elementu „zgodności motywacyjnej” (incentive compatibility) i głoszone przez romantyków hasła dzielenia się prywatną informacją. Natychmiastowa akceptacja w warunkach rynku dwustronnego rodzi niebezpieczeństwo ujawnienia preferencji, natomiast algorytm z zasadą „odroczonej akceptacji” czyni wprawdzie nieco więcej komfortu, ale jest jeszcze daleko do ideału. Tylko na rynku jednostronnym, jakim jest np. rynek nieruchomości (mieszkań, domów - housing market) każdy może bez obaw ujawniać swoje preferencje.

Istotny krok w kierunku badań empirycznych uczynił Roth w latach 80., analizując zbiory „targowisk”, w tym rynek pracy, miejsc internetowych i hotelowych dla personelu medycznego ${ }^{19}$. Zgromadzona informacja pozwoliła odkryć ekwiwalentność algorytmu Gale-Shapleya z praktyką reformowania amerykańskiego rynku kojarzenia absolwentów medycyny z zatrudnieniem w szpitalach. W latach 50. przyniosło to organizację biur pośrednictwa (clearinghouses), które częściowo usprawniły praktykę. Roth uogólnił tezę o podobieństwie postaw wielu „targowisk”, występujące podczas takich zjawisk jak niepowodzenie, niewydolność i bankructwo (failures), i - rzadziej - także w okresie powrotu do zdrowia (recoveries). Dla sztuki projektowania rynków oznaczało to zawężenie pola badań i eksperymentowania do czterech cech

18 Interesującą tezę o roli targowisk w procesach transakcji znajdujemy w: A. E. Roth, Marketplace Institutions Realated to the Timing of Transactions, Working Paper NBER 16556, November 2010.

19 A. Roth, The Evolution of the Labor Market for Medical Interns and Residents: A Case Study in Game Theory, „Journal of Political Economy”, 1984, vol. 92, s. 425-427. 
rynków: gęstości (thickness), zapchania (korki, congestion), bezpieczeństwa (safety) i prostoty (simplicity). Według Rotha, dzieje amerykańskich „targowisk” na rynku absolwentów uczelni medycznych można rozpatrywać w następujących okresach: 1) 1900-1945, kiedy rozplątywano sieć słabych rynków, rozproszonych, ale oferujących coraz więcej młodych lekarzy; 2) lata 1945-1951, rynki były zagęszczone, zatory, decyzje o tworzeniu biur pośrednictwa; 3) od 1951 r. wdrażane są programy oparte na doskonalszych algorytmach, testowane i obejmujące wciąż nowe obszary. Wyzwaniem jest teraz stabilność alokacji w zmieniających się strukturach rynkowych.

W tym miejscu warto wspomnieć o działalności Narodowego Programu Alokacji Personelu (NRMP - National Resident Matching Program) - organizacji pozarządowej i non-profit powołanej w Stanach Zjednoczonych do życia w 1952 r. w celu niesienia pomocy studentom szkół medycznych w dostępie do akademików i prywatnych kwater ${ }^{20}$. Wiara w skuteczność zdecentralizowanego konkurencyjnego rynku okazała się złudzeniem, ponieważ szpitale ostro walczyły o pozyskanie stażystów i werbowano ich dwa lata przed zdobyciem dyplomu. Studenci nie byli jednak zadowoleni z pierwszych rozwiązań reformy, jako preferujących interesy szpitali. Pojawiły się modyfikacje i nowe algorytmy, które uwzględniły problem zapewnienia pracy małżeństwom młodych lekarzy w jednym szpitalu i w jednym mieszkaniu. Daje znać o sobie wzrost znaczenia różnych gałęzi medycyny i nie znika tradycyjne żądanie, aby jeden $\mathrm{z}$ małżonków nie był bardziej szczęśliwy. Preferencje współmałżonków nie tworzą absolutnej jedności jako pary, nieczęsto udaje się skorzystać z zasady odroczonej zgody i najogólniej - codzienność „skrzeczy”. Nic dziwnego, że oprócz NRMP działają także inne programy alokacji na tego typu rynkach (np. Scramble i SOAP) i wciąż praktykowane jest tradycyjne poszukiwanie na własne ryzyko. Sam Roth nie odmawia współpracy z młodymi specjalistami i wciąż oddziałuje twórczo na wyzwania praktyki ${ }^{21}$.

W twórczości Rotha i związanego z nim także nieformalnego zespołu młodych naukowców pojawiła się tendencja do scalenia rozproszonych koncepcji w poręczne układy powiązań, przenoszące podobieństwo rodziny algorytmów na różne pola badawcze. To co zyskało już uznanie, jak jest z problemem stabilnych małżeństw, okazało się dość łatwe w adaptacji do zagadnienia rekrutacji do wyższych szkół (college admissions problem) i nawet do tak trudnego procesu jak pozyskiwanie organów (nerek) do przeszczepów. Za sku-

${ }^{20}$ NRMP homepage. http://www.nrmp.org/ [data pobrania: 4.01.2013].

${ }^{21}$ Roth A., Elliott P., The Redesign of the Matching Market for American Physicians: Some Engineering Aspects of Economic Design, „The American Economic Review”, 1999, vol. 89, s. 748-780 . 
teczne wdrożenie osiągnięć teorii gier do takich struktur współczesnych ustrojów społeczno-gospodarczych Nagroda Nobla znalazła już szeroką aprobatę środowisk naukowych i w kręgach opinii publicznych. Przypomnę tylko kilka faktów.

Najpierw te związane $\mathrm{z}$ wyborem uczelni i wyrastające $\mathrm{z}$ koncepcji określonej mianem algorytmu Gale-Shapleya, które przyniosły skuteczne wdrożenie systemu naboru i kwaterowania wyższych szkół Nowego Jorku ${ }^{22}$. Do roku 2003 kandydaci musieli w swoich podaniach wymienić 5 preferowanych szkół, a ich listy rozpatrywały szkoły - przyjmując, odrzucając lub wpisując na listę oczekujących. Procedura miała dwie rundy i odrzuconym pozostawała tylko droga administracyjna. Szacowano, że rocznie ok. 30 tys. kandydatów nie dostawało się do tych uczelni. Analitycy uznali ten proces za motywacyjnie niezgodny, tj. brzemienny w próby ukrycia prawdziwych preferencji aplikanta, jako że uczelnie preferowały studentów umieszczających ich uczelnie na pierwszym miejscu. Zespół Rotha przeprojektował system naboru - w jednym podaniu student jasno określał preferencje i deklarował zasadę odroczonej zgody oraz znajomość lokalnych regulacji. System likwidował zatory i już w pierwszym roku obniżył dziesięciokrotnie liczbę odrzuconych kandydatów.

Bliski terytorialnie i gospodarczo System Bostońskich Szkół Publicznych (Boston Public School System) opierał się na sprawnym urzędzie pośrednictwa i zasadach dość ostrego algorytmu. Preferowano wybór pierwszej szkoły aż do wyczerpania jej możliwości, aby potem czynić tak z następnymi. Niezadowolenie, zwłaszcza rodziców, z takim wyborem doprowadziło do publicznych dyskusji i wdrożenia nowego algorytmu dla potrzeb lokalnego biura werbunkowego. Tylko małe modyfikacje wprowadzono do już wdrożonego rozwiązania nowojorskiego. Specyfika Bostonu zbliżyła to podejście do układu rynku $z$ jednostronnym problemem alokacji ${ }^{23}$. Potwierdzone sukcesy ciągle doskonalonych algorytmów i wymierne korzyści zapewniły wdrażanie procedur przez kolejne systemy szkół publiczny w Denver i Nowym Orleanie.

$\mathrm{Na}$ zakończenie przeglądu osiągnięć Rotha w obszarze projektowania wdrażania rynków mających duże znaczenie we współczesnych realiach pozwalam tylko na kilka uwag. Upowszechniony już problem wymiany ludzkich organów do wykonywania przeszczepów (transplantacji) zrodził potrzebę za-

\footnotetext{
22 A. Abdulkadiroglu, P. A. Pathak, A. Roth, The New York City High School Match, „American Economic Review. Papers and Proceedings", 2005, vol. 95 (2), s. 364-371. Polecam także: Z. Świtalski, Optymalny system rekrutacji kandydatów do szkót, „Badania Operacyjne i Decyzje”, 2005, nr 3-4 oraz O kojarzeniu matżeństw i rekrutacji kandydatów do szkót, „Roczniki Polskiego Towarzystwa Matematycznego”, Seria II, Wiadomości Matematyczne XLIV (2008).

${ }^{23}$ A. Abdulkadiroglu, P. A. Pathak, A. Roth, T. Sönmez, Changing the Boston School Choice Mechanism: Strategy-Proofness as Equal Acces working paper 2007.
} 
jęcia stanowiska wobec decyzji sugerowanych przez etykę i ekonomię. Relacja między dawcą i biorcą, może być kształtowana w rodzinnej atmosferze, głębokiej przyjaźni i zgodnie ze światopoglądem pary donator-odbiorca. Szybko wykryto przeszkody - konflikt grup krwi i szybkość pokonania odległości w dostawie organu. Pojawiła się także strefa biznesu i wymiana budząca także wstręt i ocierająca się o przestępstwo. W Stanach Zjednoczonych ustawa National Organ Transaplantation Act z 1984 r. zakazała handlu ludzkimi organami i powołała urząd zawierania wiążących kontraktów przez szpitale dokonujące przeszczepu. Konieczne jest obustronne uzgodnienie każdego kroku w procedurze. Oznacza to jednak tylko powołanie struktur quasi-prawnych, łatwo wpadających w szarą strefę i brzemienną w konflikty społeczne. Nic dziwnego, że Roth i liczne już grono jego współpracowników skupia wysiłek na niezwykle dynamicznie rozwijający się amerykański rynek wymiany nerek do przeszczepów, który stawał się coraz bardziej komercyjny i regulowany przez mechanizmy cenowe.

Jako próba wdrożenia „wymiany przyjaznej” (exchange „in kind”) powstała struktura organizacyjna rynku wymiany nerek na historycznym terytorium Nowej Anglii, obejmującym 6 sąsiednich stanów w północno-wschodnim USA. Dostępna jest bogata literatura i osobista ocena programu A.Rotha w jego wykładzie noblowskim ${ }^{24}$. Algorytm ujmuje więzi między parami (dawca-biorca) i ich następstwa - łańcuchy równoczesnych operacji chirurgicznych. Obliczenia nie są łatwe, jeśli za jednostkę obrachunkową weźmiemy dwustronną wymianę, która pociąga 4 równoczesne operacje, a na kontrolowanym terytorium są dziesiątki par. Stąd też wynika paradoks - więcej par daje większe możliwości, ale ogranicza poważnie ilość operacji. Tu już wkracza teoria grafów i rodzi kolejne wyzwania.

Kwestia podstawowa - czy handel nerkami (szerzej - ludzkimi organami) do transplantacji jest ciężkim przestępstwem? Roth wypowiada się wymijająco - pozwólcie myśleć o odrazie (obrzydzeniu) jako ograniczeniu rynków. Uczony powinien rozumieć nieco więcej o transakcjach ekonomicznych i biznesowych niż zwykły przedstawiciel ludu. A jak ma rozwijać się projektowanie targowisk? Dla potrzeb rynku np. absolwentów ekonomii pojawiają się interesujące publikacje opowiadające się za poskramianiem przepychanek i życzliwym sygnalizowaniem sytuacji, zwłaszcza na dopiero rodzących się ośrodkach nowych gałęzi medycyny. Roth dobrotliwie mówił o koncep-

${ }^{24}$ A. E. Roth, T. Sönmez, M. U. Ünver, A kidney Exchange clearinghouse in New England, „American Economic Review”, 2005, vol. 95, s. 376-380 oraz Efficient kidney exchange: Coincidence wants in market with compatibility-based preferences, „American Economic Review”, 2007, vol. 97 , s. $828-851$. 
cjach wolnego rynku, zwykle wyobrażanych jak koło, obracające się wokół osi i w dobrze naoliwionym łożysku. Jako przesłanie $z$ wysokiej trybuny, kierowane do inżyniera-ekonomisty, wymienił korzystanie $z$ teorii gier i jej modeli gry koalicyjnej, wnikliwej obserwacji reguł w badaniach empirycznych i testach ekonomiki eksperymentalnej ${ }^{25}$. Wszystkim powinna być bliska teza, że współdziałanie teorii i praktyki prowadzi do nowych rodzajów teorii.

\section{ZAKOŃCZENIE}

Trzeba pamiętać, że Nagroda Nobla jest stałym obiektem zainteresowania nie tylko świata nauki, ale także ideologii i polityki. Dotyczy to również tych nagród w ekonomii, które ufundował w 1969 r. Bank Szwecji Analizuje się nie tylko trendy w rozwoju struktury powszechnej myśli ekonomicznej, ale także krytykuje się uzasadnienia ogłaszane przez jury, podtrzymujące twórczą dyskusje między wielkimi szkołami i kierunkami współczesnej ekonomii. Sądzę, że aktualna nagroda nie miała charakteru zaskoczenia, ale jednocześnie umocniła miejsce ekonomii matematycznej i teorii gier zajmowane wciąż przez mainstream, mimo ponawiających się prób jego osłabienia i nawet degradacji. Godną wyróżnienia jest postawa Jury, wskazująca na wzajemny związek i uwarunkowanie teorii i praktyki oraz twórcze łączenie dorobku pokoleń uczonych, mistrzów i następców.

\section{BIBLIOGRAFIA}

Abdulkadiroglu A., Pathak P. A., Roth A., The Nerw York City High School Match, „American Economic Review. Papers and Proceedings”, 2005, vol. 95 (2), http:// dx.doi.org/10.1257/000282805774670167.

Abdulkadiroglu A., Pathak P. A., Roth A., Sönmez T., Changing the Boston School Choice Mechanism: Strategy-Proofness as Equal Access (working paper) 2007.

Abella A., The RandCorporation: The Think TanknThat Controls America, http://mentalfloss.com/article/22120/rand-corporation [data pobrania:4.01.2013].

Aumann R. J., Game theory, „The New Palgrave, A Dictionary of Economics”, 1998, vol. 2, http://dx.doi.org/10.1057/9780230226203.0615.

Aumann R. J., Shapley L. S., Values of Non-Atomic Games, Princeton University Press 1974.

25 A. E. Roth, On the Early History of Experimental Economics, "Journal of the History of Economic Thought”, 1993, 15, Fall, s. 184-209. 
Blajer-Gołębiewska A., Zielenkiewicz M., Teoria gier jako narzędzie ekonomii XX i XXI wieku, [w:] D. Kopycińska (red.), Teoretyczne aspekty gospodarowania, Wyd. Katedry Mikroekonomii Uniwersytetu Szczecińskiego, Szczecin 2005.

Bondareva O. N., Some applications of linear programming methods to the theory of cooperative games in Russian, „Problemy Kybernetiki” 1963, vol. 10.

Gale D., Shapley L., College Admissions and the Stability of Marriage, 1962.

Kilborn P., Fresh water Economists Gain, „New York Times”, http://query. Nytimes. com [data pobrania: 4.01.2013].

Killion M. U., Relation of Game Theory to Economic History and Marginalism, http:// mpra.ub.uni-muenchen.de/13380/1/MPRA_paper_13380.pdf [data pobrania: 4.01.2013], http://dx.doi.org/10.2139/ssrn.1341825.

Malawski M., Robert Aumann, „Zeszyty Naukowe Akademii Leona Koźmińskiego”, 11 czerwca $2009 \mathrm{r}$.

NRMP homepage, http://www.nrmp.org/ [data pobrania: 4.01.2013].

Płatkowski T., Wstęp do teorii gier, Uniwersytet Warszawski, Warszawa 2012.

Roth A., Elliott P., The Redesign of the Matching Market for American Physicians: Some Engineering Aspects of Economic Design, „The American Economic Review”, 1999, vol. 89, http://dx.doi.org/10.1257/aer.89.4.748.

Roth A. E., Marketplace Institutions Related to the Timing of Transactions, NBER Working Paper 16556, November 2010, http://dx.doi.org/10.1086/663621.

Roth A.E., On the Early History of Experimental Economics, "Journal of the History of Economic Thought", 1993, 15, Fall, s. 184-209, http://dx.doi.org/10.1017/ S1053837200000936.

Roth A. E. (ed.), The Shapley value, essays in honor of Lloyd S. Shapley .Cambridge University Press, 1988.

Roth A. E., Sönmez T., Ünver M. U., $A$ kidney Exchange Clearinghouse in New England, „American Economic Review”, 2005, vol. 95, http://dx.doi. org/10.1257/000282805774669989.

Roth A. E., Sönmez T., Ünver M. U., Efficient kidney exchange: Coincidence wants in market with compatibility-based preferences, „American Economic Review”, 2007, vol. 97, http://dx.doi.org/10.1257/aer.97.3.828.

Roth A. E., The Art of Designing Markets, „Harvard Business Review”, Oct. 2007.

Roth A. E., The Evolution of the Labor Market for Medical Interns and Residents: A Case Study in Game Theory, "Journal of Political Economy", 1984, vol. 92, http:// dx.doi.org/10.1086/261272.

Roth A. E., What have we learned from market design? „Economic Journal” 2008, http://dx.doi.org/10.1111/j.1468-0297.2007.02121.x.

Schelling T. C., Micromotives and Macrobehavior, Norton 1978.

Shapley L., Scarf H., On cores and indivisibility, „Journal of Mathematical Economics", 1974, vol. 1, s. 30-44, http://dx.doi.org/10.1016/0304-4068(74)90033-0.

Shapley L. S., A Value for n-person Games, „Annals of Mathematical Studies”, 1953, vol. 28, Princeton University Press, http://dx.doi.org/10.1017/CBO9780511528 446.003 . 
Shapley L. S., Values of large market games: Status of the problem, RM-3957-PR, The Rand Corporation, Santa Monica 1964.

Shapley L. S., Gale D., College Admissions and the Stability of Marriage, „The American Mathematical Monthly", 1962, vol. 69.

Shapley L. S., On balanced sets and cores, „Naval Research Logistics Quarterly”, 1967, vol. 14, http://dx.doi.org/10.1002/nav.3800140404.

Shapley L.S., Shubik M., The Assignment Game I: The Core, „International Journal of Game Theory", 1971, vol. 1, http://dx.doi.org/10.1007/BF01753437.

Shapley L. S., Shubik M., A Method for Evaluating the Distribution of Power in a Committee System, „American Political Science Review”, 1954, vol. 48, http://dx.doi. org/10.2307/1951053.

Shapley L. S., Shubik M., On Market Games, „Journal of Economic Theory”, 1967, vol. 1, http://dx.doi.org/10.1016/0022-0531(69)90008-8.

Stankiewicz W., O projektowaniu mechanizmów spotecznych, „Ekonomista”, 2009, nr 3.

Świtalski Z., Optymalny system rekrutacji kandydatórw do szkót, „Badania Operacyjne i Decyzje", 2005, nr 3-4.

Świtalski Z., O kojarzeniu matżeństw i rekrutacji kandydatów do szkót, „Roczniki Polskiego Towarzystwa Matematycznego", Seria II, Wiadomości Matematyczne XLIV (2008). 
